8. Про судову практику у справах про перевищення влади або службових повноважень : постанова Пленуму ВСУ від 26 груд. 2003 р. № 15. Абз. 2 п. 5.

9. Інформація від 8 серпня 2016 р. зі сторінки Facebook Департаменту внутрішньої безпеки Національної поліції України. URL: https://www.facebook.com/959666410789182/photos/a.9626 45293824627.1073741828.959666410789182/1072348196187669/?type=3.

10. Про Національну поліцію : Закон України від 2 лип. 2015 р. № 580-VIII. Урядовий кур 'єр. 2015. № 146.

11. Перевищили службові повноваження: у справі горе-поліцейських є нові деталі URL: https://sud.ua/ru/news/ukraine/136492-perevischili-sluzhbovi-povnovazhennya-u-spravi-gorepolitseyskikh-ye-novi-detali.

УДК 343.2

DOI https://doi.org/10.32844/2618-1258.2019.3-2.18

ГАЛЮК А.В.

\title{
ЗАГАЛЬНА ХАРАКТЕРИСТИКА ДІЯЛЬНОСТІ ЩОДО ЗАПОБІГАННЯ ТА ПРОТИДІЇ НАРКОМАНІЇ НА РЕГІОНАЛЬНОМУ РІВНІ
}

Визначено, що основними ознаками запобігання та протидії наркоманії на регіональному рівні $є$ : 1) поєднання політичної волі керівництва держави із зусиллями місцевих органів влади, органів місцевого самоврядування, громадськості; 2) спрямована на дотримання балансу превентивних, контрольних лікувально-профілактичних, медико-соціальних та каральних заходів, які мають реалізовуватися як під час протидії незаконному обігу наркотиків, так і під час забезпечення їх доступності в медичних цілях з урахуванням наркоситуації в цілому по державі та iii окремих регіонах; 3) здійснюється у результаті залучення коштів державного та місцевих бюджетів, міжнародної технічної та донорської допомоги; 4) на перший план висувається пріоритет превентивного та лікувально-профілактичного складників за рахунок пом'якшення кримінально-правового спрямування антинаркотичних заходів; 5) протидія поширенню наркотичної субкультури в суспільстві, особливо серед тих категорій осіб, що потрапляють до «групи ризику»; 6) переважна кількість заходів регулюється нормами адміністративного права. До числа заходів щодо профілактики наркоманії слід віднести такі: загального характеру, вибіркового характеру, індикативного характеру. Зроблено висновок, що під діяльністю щодо запобігання та протидії наркоманії на регіональному рівні як об'єктом адміністративно-правового регулювання слід розуміти врегульовану нормами адміністративного законодавства сукупність заходів превентивного, контрольного, лікувально-профілактичного, медико-соціального та карального характеру, які реалізовуються на регіональному та місцевому рівнях уповноваженими на те суб'єктами з метою систематичного моніторингу та своєчасного врегулювання наркоситуації у напрямі упорядкування процедури легального обігу наркотиків (зокрема, виробництва та реалізації нарковмісних лікарських засобів), вироблення дієвого механізму зменшення обсягу пропонування наркотиків, зниження попиту на них, повернення (реінтеграція) хворих на наркоманію до нормального життя, подолання проявів стигматизації.

Ключові слова: обіг наркотиків, протидія наркоманії, правоохоронні органи, наркотики.

(C) ГАЛЮК А.В. - здобувач (Науково-дослідний інститут публічного права) 
It is determined that the main features of prevention and combating drug addiction at the regional level are: 1) the combination of political will of the state leadership with the efforts of local authorities, local self-government bodies, the public; 2) aimed at maintaining the balance of preventive, control treatment, prevention, medico-social and punitive measures, which should be implemented both in the fight against drug trafficking and in ensuring their availability for medical purposes, taking into account the drug situation in the whole country and its individual regions; 3) is carried out as a result of attraction of state and local budgets, international technical and donor assistance; 4) and priority is given to the priority of the preventive and treatment-andprophylactic component at the expense of the mitigation of the criminal-law direction of anti-narcotic measures; 5) counteracting the spread of the drug subculture in society, especially among those categories of persons at risk; 6) the overwhelming number of measures is regulated by the rules of administrative law. Among the measures for the prevention of drug addiction include the following: general, selective, indicative. It is concluded that under the activities on prevention and combating drug addiction at the regional level as an object of administrative and legal regulation should be understood set of rules of administrative legislation set of preventive, control, treatment, preventive, medico-social and punitive measures implemented at the regional level local authorities authorized by the subjects for the purpose of systematic monitoring and timely regulation of drug situation in the direction of ordering units of legal drug trafficking (in particular the production and sale of drug-containing drugs), developing an effective mechanism for reducing the supply of drugs, reducing the demand for them, returning (reintegration) patients with drug addiction to normal life, overcoming the manifestations of stigma.

Key words: drug trafficking, drug addiction, law enforcement, drugs.

Вступ. Однією із найбільш актуальних сучасних суспільних проблем є стрімке поширення наркоманії та наркозлочинності, що здійснює деструктивний вплив на здоров'я людини, стан законності та правопорядку в державі через криміналізацію людей, що вживають наркотики, створює загрози належному функціонуванню соціальної сфери та забезпеченню національної безпеки держави загалом. Вкрай негативним наслідком наркоманії є стрімке зростання кількості наркотично залежних людей, поширеність вірусу імунодефіциту серед тих людей, хто вживає наркотики, захворюваність на СНІД та наявність випадків смерті від СНІДу або передозування наркотиків.

У 2011 році Україна посіла перше місце серед країн Європи за кількістю споживачів ін'єкційних наркотиків (не за медичним призначенням). Станом на весну 2019 року таких осіб налічувалося вже понад 346 тис. Що ж стосується кількості осіб, які вживають наркотики неін'єкційним шляхом, то іiї визначити важко через те, що постійно з'являються нові психоактивні речовини 3 різними формами вживання, зростає кількість осіб, хворих на полінаркоманію.

Постановка завдання. Метою статті $є$ загальна характеристика діяльності щодо запобігання та протидії наркоманії на регіональному рівні.

Результати дослідження. Наркоманія здійснює деструктивний вплив на здоров'я людини, зокрема, через поширення ВІЛ-інфекцій, захворюваності на СНІД, гепатитів В і С, інфекцій, що передаються статевим шляхом. Так, слід звернути увагу, що Україна посідає одне 3 перших місць у світі за кількістю ВІЛ-позитивних людей, а регіон Східної Європи та Центральної Азії, до якого територіально належить і Україна, єдиний у світі, де продовжує зростати кількість людей, хворих на ВІЛ та СНІД. Найвищі рівні поширеності ВІЛ-інфекції зареєстровано в Одеській (898,3 на 100000 населення), Дніпропетровській $(792,6)$, Миколаївській $(743,5)$ областях, м. Київ $(479,0)$, Київській $(447,9)$, Херсонській $(420,1)$ та Чернігівській $(420,4)$ областях [1]. Варто зазначити, що останні спостереження (починаючи з 2014 року) не повністю відображають усю ситуацію з поширенням захворювань на ВІЛ та СНІД по регіонах нашої держави: не враховуються дані з Автономної Республіки Крим, окремих регіонів Донецької та Луганської областей, що пов'язано із проведенням там операції Об'єднаних сил та анексією Криму.

Що стосується загрози національній безпеці держави, яку несе у собі наркоманія, хотілося б пояснити, що наркотики та наркотичні речовини потрапляють на територію України завдяки діяльності міжнародних наркосиндикатів, якими вироблено ефективний механізм потрапляння за сприяння організованих дилерів наркотиків на територію держави, здійснення їх транзитного пе- 
реміщення та реалізації. Крім того, діяльність щодо незаконного поширення наркотичних засобів часто поєднується зі вчиненням правопорушень, пов'язаних з корупцією, тероризмом, що у своїй сукупності створює істотну загрозу стану законності та правопорядку як на загальнодержавному, так і регіональному рівні.

Таким чином, ситуація, що сьогодні склалася у сфері обігу та вживання не за медичним призначенням наркотиків, наркотичних засобів та прекурсорів, вимагає свого негайного вирішення на міжнародному, загальнодержавному та регіональному рівнях шляхом систематичного моніторингу та своєчасного врегулювання наркоситуації у напрямі упорядкування процедури легального обігу наркотиків (зокрема, виробництва та реалізації нарковмісних лікарських засобів), вироблення дієвого механізму зменшення обсягу пропонування наркотиків, зниження попиту на них, повернення (реінтеграція) хворих на наркоманію до нормального життя, подолання проявів стигматизації.

Зважаючи на викладене вище, важливого значення набуває вироблення дієвої державної політики щодо протидії наркотикам, орієнтованої на: 1) вироблення механізму моніторингу наркоситуації в державі та іiі окремих регіонах; 2) своєчасну ідентифікацію загроз, що несе у собі нелегальний обіг наркотиків (для стану правопорядку в державі та іiї окремих регіонах, здоров' я населення, належного функціонування соціальної сфери), порушення встановлених процедур легального обігу наркотиків, вживання не за медичним призначенням наркотичних лікарських засобів, що може викликати наркотичну залежність; врегулювання процедури доступу до наркотичних лікарських засобів шляхом спрощення процедури їх обігу в медичних та наукових цілях; 3) зменшення обсягу незаконного розповсюдження наркотиків на території всієї держави та в окремих iï регіонах, наркоситуація в яких є такою, що становить загрозу правопорядку, фізичному та моральному здоров'ю населення (тобто з урахуванням специфіки окремих регіонів); 4) організацію раннього виявлення незаконного вживання наркотиків як передумови запобігання захворюванням та ефективного лікування від наркозалежності [2]; 5) подолання проявів стигматизації та дискримінації наркоспоживачів у суспільстві; 6) адаптацію наркозалежних у соціумі; 7) створення умов для унеможливлення функціонування наркобізнесу, істотне послаблення його економічних засад; 8) налагодження взаємодії органів державної влади, що є основними суб'єктами протидії наркоманії на загальнодержавному та регіональному рівнях, з інституціями громадянського суспільства у напрямі формування та реалізації відповідної політики.

Наведене вище і обгрунтовує актуальність дослідження проблематики діяльності щодо запобігання та протидії наркоманії, зокрема на регіональному рівні.

Загалом погоджуючись із запропонованою О.І. Безпаловою точкою зору щодо трактування державної політики у правоохоронній сфері [3, с. 103; 4], пропонуємо під державною політикою щодо протидії наркотикам розуміти визначений на рівні стратегічних нормативно-правових актів та політичних рішень курс держави щодо протидії незаконному обігу наркотиків, забезпечення їх доступності в медичних цілях з урахуванням наркоситуації в цілому по державі та іiі окремих регіонах, профілактики наркоманії, надання медико-соціальної допомоги особам, хворим на наркоманію, та ресоціалізації наркозалежних осіб. Реалізація державної політики щодо протидії наркотикам відбувається за допомогою відповідних превентивних, контрольних, лікувально-профілактичних, медико-соціальних та каральних заходів.

Варто зазначити, що в сучасних реаліях важливого значення набуває превалювання у державній політиці щодо наркотиків превентивного та лікувально-профілактичного складника, пом'якшення кримінально-правового спрямування антинаркотичних заходів. Це зумовлено необхідністю врахування антропоцентричного підходу, зміст якого полягає в тому, що людина, іiі життя, здоров'я, права та законні інтереси, недоторканість та безпека визнаються найвищою соціальною цінністю, на забезпечення яких має бути спрямована діяльність усіх суб'єктів протидії наркотикам. Зважаючи на це, під час формування державної політики щодо наркотиків необхідно забезпечити дотримання балансу превентивних, лікувально-профілактичних, медико-соціальних та каральних заходів, які мають реалізовуватися як під час протидії незаконному обігу наркотиків, так і під час забезпечення їх доступності в медичних цілях з урахуванням наркоситуації в цілому по державі та іiї окремих регіонах.

Державна політика щодо наркотиків має реалізовуватися на міжнародному, загальнодержавному та регіональному рівнях. Зміст міжнародного співробітництва у вказаній сфері полягає у спільних зусиллях правоохоронних органів України, інших держав, міжнародних правоохоронних інституцій та неурядових організацій щодо боротьби з незаконним переміщенням та споживанням наркотиків шляхом: а) спільної розробки та реалізації міжнародних угод, програм i 
проектів щодо протидії наркоманії; б) залучення міжнародних експертів для надання підтримки у створенні національної координаційної міжвідомчої розвідувальної системи щодо наркотиків, вдосконалення процедури збору даних, навчання експертів у сфері епідеміології, посиленні громадської безпеки [5]; в) проведення наукових досліджень у галузі прогнозування процесів у сфері обігу наркотиків, запобігання негативним наслідкам поширення наркоманії та наркозлочинності, у тому числі протидії ним, а також лікування наркотичної залежності; г) проведення комплексних заходів із залученням представників правоохоронних органів різних країн з метою виявлення контрабанди наркотиків, припинення корупційних схем, що мають до цього відношення; д) обміну стратегічною інформацією та досвідом щодо профілактики наркоманії (скорочення попиту та пропозиції), лікування та реабілітації хворих на наркоманію.

На загальнодержавному рівні реалізація державної політики щодо наркотиків відбувається з урахуванням положень низки нормативно-правових актів, зокрема, Стратегії державної політики щодо наркотиків на період до 2020 року, яка, власне, визначає сутність та сучасні напрями державної політики щодо наркотиків, що формується на засадах інтегрованого і збалансованого підходу до зменшення обсягу пропонування наркотиків, що знаходяться в незаконному обігу, та зниження попиту на них, подолання наркоманії як небезпечного соціального явища [2].

Що стосується регіонального аспекту державної політики щодо наркотиків, то його зміст полягає у виробленні та реалізації на місцевому та регіональному рівнях відповідних програм, які формуються згідно з принципами та підходами Стратегії державної політики щодо наркотиків на період до 2020 року та визначають, зокрема, такі заходи: а) сприяння розробленню та реалізації на регіональному та місцевому рівнях наркополітики, яка повинна базуватися на сучасних науково обгрунтованих просвітницьких методах, методах профілактики, раннього виявлення та лікування наркотичної залежності; б) забезпечення належного фінансування регіональних і місцевих антинаркотичних програм за рахунок відповідних бюджетів; в) створення на рівні місцевих громад системи реабілітаційних закладів; г) актуалізація змісту діяльності комісій при обласних і районних адміністраціях залежно від наркоситуації в регіоні [2].

У результаті аналізу наведених вище заходів, що мають впроваджуватися на регіональному рівні з метою реалізації державної політики щодо наркотиків, можна дійти висновку щодо відсутності згадки про пріоритет діяльності правоохоронних органів у сфері протидії незаконному обігу наркотиків. Тобто наведений перелік містить переважно превентивні, лікувально-профілактичні та медико-соціальні заходи, причому превентивні заходи мають здійснюватися місцевими органами влади та органами місцевого самоврядування. Практично відсутня правоохоронна спрямованість реалізації державної політики щодо наркотиків; жоден із наведених заходів не стосується безпосередньої протидії незаконному обігу і розповсюдженню наркотиків, незаконному їх переміщенню через державний кордон та перевезенню до цільових точок постачання, виявлення та документування незаконної діяльності організованих злочинних груп, усунення корупційного складника всередині правоохоронних органів, до повноважень яких належать протидії незаконному обігу наркотиків, тощо. У зв'язку з цим, на нашу думку, доцільно внести відповідні доповнення до Стратегії державної політики щодо наркотиків на період до 2020 року в розрізі регіонального аспекту наркополітики, якими передбачити збільшення акцентів на діяльність правоохоронних органів.

Зважаючи на викладене вище, вважаємо за доцільне виокремити основні напрями діяльності щодо запобігання та протидії наркоманії на регіональному рівні: а) упорядкування та здійснення контролю за дотриманням процедури легального обігу наркотичних засобів, психотропних речовин і прекурсорів, а також лікарських засобів, що їх містять; б) протидія незаконному обігу наркотичних засобів, психотропних речовин і прекурсорів, а також лікарських засобів, що ïx містять; в) профілактика наркоманії; г) упорядкування процедури надання медико-соціальної допомоги особам, хворим на наркоманію, ресоціалізації наркозалежних осіб. У рамках кожного із напрямів діяльності щодо запобігання та протидії наркоманії на регіональному рівні здійснюється низка заходів. Розглянемо основні з них більш детально.

Що стосується діяльності щодо упорядкування та здійснення контролю за дотриманням процедури обігу наркотичних засобів, психотропних речовин і прекурсорів, а також лікарських засобів, що їх містять, то у рамках цього напряму здійснюється низка заходів, зокрема: 1) упорядкування процедури господарської діяльності з виробництва лікарських засобів, оптової та роздрібної торгівлі лікарськими засобами, імпорту лікарських засобів (крім активних фармацевтичних інгредієнтів); 2) контроль за розробленням, виробництвом, виготовленням, зберіганням, перевезенням, придбанням, реалізацією (відпуском), ввезенням на територію України, вивезенням з території України, використанням, знищенням наркотичних засобів, психотропних речовин 
і прекурсорів; 3) визначення переліку засобів психотропних наркотичних речовин і прекурсорів, систематичний перегляд засобів, що входять до цього переліку, а також квот на кожен рік щодо культивування рослин, що містять наркотичні засоби і психотропні речовини, виробництво, виготовлення, зберігання, ввезення на територію України та вивезення з території України наркотичних засобів і психотропних речовин; 4) видача ліцензій та дозвільних документів на окремі види господарської діяльності, пов'язаної з виробництвом, виготовленням, зберіганням, ввезенням на територію України та вивезенням з території України наркотичних засобів і психотропних речовин, оптової та роздрібної торгівлі лікарськими засобами, що містять наркотичні речовини тощо.

У рамках протидії незаконному обігу наркотичних засобів, психотропних речовин і прекурсорів, а також лікарських засобів, що їх містять, уповноваженими суб'єктами вживається низка заходів, а саме: 1) моніторинг наркоситуації як на загальнодержавному рівні, так і на рівні окремих регіонів; 2) виявлення каналів контрабандного надходження наркотичних засобів та психотропних речовин на територію нашої держави та їх транзитного перевезення; 3) виявлення в мережі Інтернет та мобільних месенджерах фактів он-лайн продажу наркотичних засобів та психотропних речовин, їх блокування; 4) проведення оперативно-розшукових та оперативно-технічних заходів 3 метою виявлення та знищення нелегальних посівів маку та конопель, нелегального культивування марихуани під виглядом інших сільськогосподарських культур, незаконних посівів нарковмисних речовин, виявлення та ліквідації підпільних нарколабораторій; 5) викриття фактів утримання притонів із незаконного вживання наркотиків; 6) виявлення фактів незаконного збуту та зберігання наркотичних засобів і психотропних речовин без мети збуту; 7) вилучення наркотичних засобів та психотропних речовин; 8) попередження та припинення проявів корупції серед працівників правоохоронних органів у сфері боротьби з незаконним обігом наркотиків.

Крім того, на регіональному рівні важливого значення набуває консолідація зусиль представників правоохоронних органів (передусім органів Національної поліції), органів місцевого самоврядування і громадськості щодо створення та забезпечення функціонування міських ресурсних центрів для боротьби з наркоманією та допомоги наркозалежним; систематичної оперативно-профілактичної роботи у навчальних, розважальних закладах та місцях масового відпочинку молоді (барах, кафе, дискотеках, нічних клубах тощо) з метою недопущення розповсюдження в них наркотичних засобів для немедичного вживання [6].

До числа заходів щодо профілактики наркоманії слід віднести такі:

а) загального характеру:

- інформування населення про шкоду та негативні наслідки вживання наркотичних засобів, психотропних речовин і прекурсорів, а також лікарських засобів, що їх містять, пропаганда здорового способу життя;

- оновлення змісту дисциплін, що викладаються у навчальних закладах, запровадження факультативних курсів, спрямованих на поглиблення знань про здоровий спосіб життя, шкоду та негативні наслідки вживання наркотичних засобів, психотропних речовин і прекурсорів;

- налагодження взаємодії місцевих органів державної влади, органів місцевого самоврядування із засобами масової інформації з метою підвищення рівня обізнаності населення про небезпеки, пов'язані зі споживанням наркотиків та проблематику підліткової наркоманії;

- проведення заходів щодо підвищення кваліфікації педагогічних працівників, лікарів 3 метою отримання ними знань щодо сучасних методик і практик раннього виявлення незаконного вживання наркотиків;

- реалізація в закладах загальної середньої освіти проекту «Шкільний офіцер поліції» [6];

- проведення із залученням громадськості інформаційно-просвітницьких, культурних заходів з метою мінімізації випадків поширення шкідливих звичок серед дітей та підлітків;

- врахування гендерних чинників під час обрання оптимальних форм та методів профілактики наркоманії;

- створення передумов для обмеження поширення наркотичних засобів та психотропних речовин серед осіб, що навчаються у навчальних закладах різних рівнів (встановлення парканів та огорож навколо територій, що прилеглі до навчальних закладів; облаштування вказаних територій камерами зовнішнього відеоспостереження; видалення надписів, що інформують про місця зберігання заборонених речовин; систематичні перевірки місць тимчасового проживання студентів з метою виявлення фактів зберігання та вживання наркотичних засобів та психотропних речовин тощо) [7];

б) вибіркового (селективного характеру), зміст яких полягає в організації спеціальної психокорекційної роботи з особами, що мають схильність до вживання наркотиків (так званими 
групами ризику). Одним із прикладів заходів такого характеру, що реалізовувався саме на регіональному рівні, $€$ проект «Надання послуг зі зменшення шкоди підліткам, які споживають наркотики, в Україні: досягти не охоплених послугами», який був реалізований у 2016 році центрами соціальних служб для сім'ї, дітей та молоді спільно з МБФ «Альянс громадського здоров'я». У ході проекту у містах Києві, Одесі, Харкові, Полтаві, Кривому Розі Дніпропетровської області та Слов'янську Донецької області апробовано нову модель надання комплексних профілактичних послуг неповнолітнім у поєднанні із змістовним та активним дозвіллям [8, с. 55]. Основними формами реалізації цього проекту були такі заходи. як індивідуальне добровільне консультування, тестування, лекції, тренінги, групові бесіди. За результатами реалізації цього проекту близько 250 дітей, які до того моменту споживали наркотичні та психоактивні речовини, відмовилися від цього. Загалом до числа профілактичних заходів вибіркового (селективного) характеру можна віднести такі: консультування, надання юридичної допомоги, соціальна профілактика, соціальний супровід (патронат), соціальна адаптація, інтеграція та реінтеграція, представництво інтересів, соціально-психологічна адаптація, медіація (посередництво), кризове та екстрене втручання, направлення до закладів охорони здоров'я, профілактичні наркологічні огляди тощо;

в) індикативного характеру (профілактика за показаннями), зміст яких полягає у застосуванні заходів щодо запобігання виникнення рецидиву хвороби. Одним із прикладів заходів, що здійснюються у цьому напрямі, $є$ запровадження у 2016 році програми диференційованого виховного впливу «Подолання алкогольної та наркотичної залежності», в якій брали участь понад 1200 осіб. У рамках програми проводилась психологічна робота із засудженими та особами, узятими під варту, які є залежними від наркотиків, що передбачала надання психологічної допомоги вищевказаним особам, розробку програм психокорекційного та педагогічного впливу на них, підвищення психологічної компетентності персоналу установ виконання покарань та слідчих ізоляторів, узагальнення та впровадження в практику роботи сучасних методів психолого-педагогічного впливу $[8$, с. 60]. Основними формами реалізації програми диференційованого виховного впливу «Подолання алкогольної та наркотичної залежності» $€$ такі: індивідуально-консультативна та корекційна робота (спостереження, анкетування, прогресивна релаксація, аутогенне дренування, арттерапія, музикотерапія, хромотерапія та інші); психопрофілактична робота (бесіди, консультування, анамнестичне опитування, лекції); консультативна та корекційна робота з малими групами; груповий тренінг для осіб, які мають ідентичні психологічні проблеми [8, с. 63-64]. Такі форми та методи можуть застосовуватися не лише для осіб, раніше хворих на наркоманію, що перебувають у місцях позбавлення волі; ця програма може бути застосована для реалізації в усіх регіонах України;

г) специфічного характеру, необхідність застосування яких зумовлена проведенням в окремих регіонах держави операції Об’єднаних сил, військового або збройного конфлікту. Як приклад реалізації такого виду заходів можна навести діяльність Міжнародного благодійного фонду «Альянс громадського здоров'я», який спільно з 11 партнерськими місцевими неурядовими організаціями був ініціатором розробки та реалізації різноманітних проектів з профілактики поширення ВІЛ-інфекцій, захворюваності на СНІД серед груп ризику (найбільш уразливих до цих хвороб категорій населення). Вказані заходи відбувалися на території 18 населених пунктів тимчасово неконтрольованої Україною території Донецької та Луганської областей та у 32 населених пунктах на контрольованій території [8, с. 64].

Останнім напрямом діяльності щодо запобігання та протидії наркоманії є упорядкування процедури надання медико-соціальної допомоги особам, хворим на наркоманію, ресоціалізації наркозалежних осіб. Цей напрям є надзвичайно важливим питанням національного рівня, ефективність реалізації якого безпосередньо залежить від якості та своєчасності втілення відповідних заходів на регіональному рівні. Регіональні наркологічні служби активно співпрацюють із неурядовими громадськими організаціями, а територіальні громадські організації надають пацієнтам, хворим на наркоманію, соціальну допомогу [8, с. 85]. В регіональному аспекті особливої уваги 3 боку держави потребують східні регіони нашої держави у зв'язку з проведенням на їх території з 2014 року антитерористичної операції, а з квітня 2018 року операції Об'єднаних сил. Це зумовлено істотним погіршенням соціально-економічної ситуації, епідеміологічної ситуації внаслідок поширення туберкульозу, ВІЛ-інфекції та захворюваності на СНІД, що є результатом ускладнення наркоситуації на території Донецької та Луганської областей, областей, що з ними межують, через велику кількість внутрішньо переміщених осіб.

Фінансування заходів щодо надання медико-соціальної допомоги особам, хворим на наркоманію, ресоціалізація наркозалежних осіб відбувається за рахунок державного та місцевих бюджетів, а також у результаті залучення міжнародної технічної та донорської допомоги. Також 
одночасно на загальнодержавному та регіональному рівнях розробляється методологія ефективного рівномірного розподілу ресурсів для надання медичної та соціальної допомоги категоріям населення, що належать до групи ризику, виконання програм замісної підтримувальної терапії.

Надання медико-соціальної допомоги особам, хворим на наркоманію, проведення замісної підтримувальної терапії, ресоціалізації наркозалежних осіб є невід’ ємним складником гуманітарної сфери, надання якої на постійній основі дозволить знизити кількість випадків захворюваності на наркоманію (і як наслідок - на ВІЛ-інфекції та захворюваності на СНІД), смертей від цього та мінімізувати випадки дискримінації людей, хворих на наркоманію. У рамках ресоціалізації та реінтеграції осіб, хворих на наркоманію, повинні реалізовуватися інформаційно-просвітницькі, соціально-культурні та оздоровчо-спортивні заходи, заходи психологічного супроводу, що дозволить сформувати у наркозалежної особи мотивації до поетапного звільнення від наркотичної залежності.

Зважаючи на проведений аналіз змісту діяльності щодо запобігання та протидії наркоманії на регіональному рівні, вважаємо за доцільне виокремити основні ознаки такої діяльності: 1) поєднання політичної волі керівництва держави із зусиллями місцевих органів влади, органів місцевого самоврядування, громадськості; 2) спрямована на дотримання балансу превентивних, контрольних лікувально-профілактичних, медико-соціальних та каральних заходів, які мають реалізовуватися як під час протидії незаконному обігу наркотиків, так і під час забезпечення їх доступності в медичних цілях з урахуванням наркоситуації в цілому по державі та іiї окремих регіонах; 3) здійснюється у результаті залучення коштів державного та місцевих бюджетів, міжнародної технічної та донорської допомоги; 4) на перший план висувається пріоритет превентивного та лікувально-профілактичного складників за рахунок пом'якшення кримінально-правового спрямування антинаркотичних заходів; 5) протидія поширенню наркотичної субкультури в суспільстві, особливо серед тих категорій осіб, що потрапляють до «групи ризику»; 6) переважна кількість заходів регулюється нормами адміністративного права.

Висновки. Підсумовуючи викладене вище, пропонуємо під діяльністю щодо запобігання та протидії наркоманії на регіональному рівні як об'єктом адміністративно-правового регулювання розуміти врегульовану нормами адміністративного законодавства сукупність заходів превентивного, контрольного, лікувально-профілактичного, медико-соціального та карального характеру, які реалізовуються на регіональному та місцевому рівнях уповноваженими на те суб'єктами з метою систематичного моніторингу та своєчасного врегулювання наркоситуації у напрямі упорядкування процедури легального обігу наркотиків (зокрема, виробництва та реалізації нарковмісних лікарських засобів), вироблення дієвого механізму зменшення обсягу пропонування наркотиків, зниження попиту на них, повернення (реінтеграція) хворих на наркоманію до нормального життя, подолання проявів стигматизації.

\section{Список використаних джерел:}

1.Епідемічна ситуація з ВІЛ-інфекції в Україні станом на 01.04.2019. URL: https://phc.org. ua/kontrol-zakhvoryuvan/vilsnid/statistika-z-vilsnidu.

2.Про схвалення Стратегії державної політики щодо наркотиків на період до 2020 року : Розпорядження Кабінету Міністрів України від 28.08.2013 р. № 735-p. URL: https://zakon.rada. gov.ua/laws/show/735-2013-\%D1\%80.

3.Безпалова О.І. Адміністративно-правовий механізм реалізації правоохоронної функції держави : монографія. Харків : НікаНова, 2014. 544 с.

4.Безпалова О.І. Правові засади реалізації державної політики у правоохоронній сфері. Право і Безпека. 2012. № 3 (45). С. 87-92.

5.План дій Україна - СС у сфері юстиції, свободи та безпеки: міжнародний документ від 18.06.2007 p. URL: https://zakon.rada.gov.ua/laws/show/994_956.

6.Про затвердження Комплексної програми з протидії поширенню наркоманії та зменшення шкоди від вживання психоактивних речовин у м. Харкові «Чисте місто» на 2019-2020 роки: Рішення Харківської міської ради Харківської області від 21.08.2019 р. № 1717/19. URL: http://kharkiv.rocks/reestr/680256.

7.«За життя без «кайфу»: створення міської програми протидії незаконному обігу наркотиків у м. Слов'янську. URL: https://e-dem.in.ua/slavyansk/Petition/View/418.

8.Національний звіт за 2017 рік щодо наркотичної ситуації в Україні (за даними 2016 року) Поглиблений огляд наркоситуації в Україні для Європейського моніторингового центру 3 наркотиків та наркотичної залежності. URL: http://www.donnuet.edu.ua/index.php/nauka/ oholoshennia/1484-natsionalnyi-zvit-za-2017-rik/file. 